\title{
Diamond Exploration Activities in Greenland
}

\author{
Bjerring, M.P. \\ Bureau of Minerals and Petroleum, Government of Greenland
}

Progress in the minerals area in Greenland was significant in 2007. The increased interest from the mineral resources industry has been driven partly by an intensive marketing of the Greenland mineral resources potential, partly by a favourable development in the price of oil, minerals and metals.

In 2007, a total of 35 new exploration licences were granted which is the highest figure in 14 years. The interest has been particularly high in gold, molybdenum, lead and zinc, eudialyte, iron, rubies and diamonds.

At the beginning of June 2008, a total of 11 prospecting licences and 64 exploration licences had been granted. The exploration licences covered an area of 24,912 sq km. Total investments in exploration in Greenland have multiplied since 2003, where an amount of 45 million DKK was spent. In 2007, total exploration expenses have amounted to 480 million DKK.

The Bureau of Minerals and Petroleum uses a one-door application process, making it unnecessary for applicants to contact other departments within the Greenland or Denmark administration. The BMP is very involved in ensuring the flow of the process and trying to foresee possible bottlenecks. These can occur within the areas of construction, transportation and hiring of qualified personnel. For the purpose of securing the highest possible social and economic gains of this development, the Bureau of Minerals and Petroleum is taking targeted initiatives in the efforts to qualify and re-group the Greenlandic workforce to the new job potential which will open as a natural consequence of the prospects of five new mines opening in the coming five years. The economic gain for Greenland will be partly increased tax revenues, partly direct employment, and the consequent effects of related trades are expected to be significant.

It is estimated that employment in the mining sector will be approx. 1,500 persons in 5 years. In the long term, the Bureau of Minerals and Petroleum assesses that the majority of the 1,500 persons will be recruited among the Greenlandic work force. To ensure this, the Bureau of Minerals and Petroleum, in cooperation with the mining industry and other relevant institutions, has set up an expert committee for the contractor and mining sector in 2007. It is the task of the Expert
Committee to coordinate all aspects concerning training and education initiatives in the mineral resources sector.

In 2007 these efforts resulted in

- a grant of 48 million DKK for the start-up of a Mining School in Sisimiut in 2008

- an upgrade in the Greenland Parliament Finance Act for 2008 of the miners' and contractors' courses at the Building and Construction School in Sisimiut, so that from 2009 an annual amount of 6.2 million DKK be set aside for this purpose

- local implementation of miners' and contractors' courses in Maniitsoq and Nanortalik

- canteen courses

- courses for heavy machinery

- language courses

In the autumn of 2007, a policy plan was prepared for the focus in the coming years, directed towards further initiatives such as the preparation of analyses on the work-force requirement in the sector, tools for managing the labour market and educational efforts, refurbishment of premises, furniture, etc., mobilitypromoting initiatives, courses directed towards people already employed in the contracting and mineral resource sector, establishment of a central recruitment office, adult training of unemployed persons, etc. The policy plan was approved by the Expert Committee in December 2007.

Another important initiative is public information meetings in the towns located in the neighbourhood of the potential new mines. The objectives of this initiative include informing the local population on the job opportunities that arise at the start-up of a mine, and informing independent contractors on the type of goods and services that are demanded by the mines. In 2006 and 2007 the Bureau of Minerals and Petroleum held meetings in Nanortalik, Qaqortoq, Uummannaq, Maniitsoq and Narsarsuaq. This effort is expected to continue in the years ahead.

\section{Diamonds}

Over the last decade there has been much focus on the diamond potential in West Greenland. The area around Kangerlussuaq and Maniitsoq has been recognized as a diamond province. This has caused much activity and 
many companies have expressed an interest in the area. There are, however, five active companies: Crew Minerals ASA, Hudson Resources Inc., Metalex Ventures Ltd., Strongbow Exploration Inc., and Avannaa Resources Ltd.

In the spring of 2007, Hudson Resources Inc. performed seismic surveys in their exploration area in the Sarfartoq region in West Greenland. The refraction survey clearly displayed a promising kimberlite occurrence. During summer, the company made drillings to confirm the seismic data. 4,500 metres were drilled in 12 holes at the locality Garnet Lake and the presence of kimberlite was confirmed. An extended drilling programme is planned for 2008.

A total of 1604 diamonds have been found in the Sarfartoq area. Of these, 441 are macro diamonds. The biggest of the diamonds is 2.4 carat, which is the biggest diamond found in Greenland to this day.

A new company in Greenland is Avannaa Resources Ltd. In 2007, the company was granted a licence at the Ataa Sound in West Greenland.

During the summer of 2007, the company has collected rock samples and an analysis of a $39 \mathrm{~kg}$ bulk sample has been made by the SGS Lakefield laboratory in Canada. This sample contained 102 diamonds with a total weight of 0.013 carat. One of these is a macro diamond of $0.83 \times 0.66 \times 0.53 \mathrm{~mm}$. The area north of where the sample is taken is described as the diamond province of West Greenland. Therefore, this sample will contribute to expanding the diamond province southwards. In 2008, the company will make additional bulk sampling and has applied for yet another exploration licence in the area.

So in actual fact we have a very optimistic image of the mineral resources exploration in Greenland. 